\title{
Drug use in Canadian patients with trauma after cannabis legalization
}

Ian M. Ball, MD, MSc

Fran Priestap, MSc

Neil Parry, MD

Jacob Pace, MD, MSc

Kelly N. Vogt, MD, MSc

Accepted July 28, 2020

\section{Correspondence to:}

I. Ball

Department of Medicine

Western University

800 Commissioners Rd E

London ON N6A 5W9

lan.ball@Ihsc.on.ca

DOI: $10.1503 /$ cjs.000620
Background: The federal Cannabis Act came into force on Oct. 17, 2018, in Canada, making Canada only the second country in the world to legalize the cultivation, acquisition, possession and consumption of cannabis and its by-products. This provided a unique opportunity to evaluate the impact of this legislation on drug-related trauma.

Methods: We performed a prospective observational study on the use of cannabis and other illicit drugs in the trauma population at a lead Canadian trauma centre in London, Ontario, in the 3 months before (July 1 to Sept. 30, 2018) and 3 months after (Nov. 1, 2018, to Jan. 31, 2019) the legalization of cannabis in Canada. We defined cannabis use as a positive cannabinoid screen result at the time of assessment by the trauma team. We also screened for opioids, amphetamines and cocaine.

Results: A total of 210 patients were assessed by our trauma service between July 1 and Sept. 30, 2018, and 141 patients were assessed between Nov. 1, 2018, and Jan. 31, 2019. Motor vehicle collisions were the most common cause of trauma both before (101 [48.1\%]) and after (67 [47.5\%]) legalization. The mean Injury Severity Score was 17.6 (standard deviation [SD] 13.0) and 19.7 (SD 14.8), respectively. Drug screens were done in 88 patients (41.9\%) assessed before legalization and 99 patients $(70.2 \%)$ assessed after legalization. There was no difference in the rate of positive cannabinoid screen results before and after legalization $(22[25 \%]$ v. $22[22 \%])$. There was a trend toward higher rates of positive cannabinoid screen results $(2 / 10$ [20\%] v. 5/8 [62\%]) and positive toxicology screen results $(5 / 10$ [50\%] v. 6/8 [75\%]) after legalization among patients with penetrating trauma, but our sample was too small to achieve statistical significance.

Conclusion: We found no difference in the rates of positive cannabinoid screen results among patients assessed at our trauma centre in the 3 months before and the 3 months after legalization of cannabis; however, there was a trend toward an increase in the rates of positive results of toxicology screens and cannabinoid screens among those with penetrating trauma. These preliminary single-centre data showing no increased rates of cannabis use in patients with trauma after legalization are reassuring.

Contexte : La Loi fédérale sur le cannabis est entrée en vigueur ici le 17 octobre 2018, faisant du Canada le second pays à légaliser la culture, l'acquisition, la possession et la consommation du cannabis et de ses produits dérivés. Cette situation fournit une occasion unique d'évaluer l'impact de cette loi sur les traumatismes liés aux drogues.

Méthodes : Nous avons procédé à une étude d'observation prospective sur la consommation du cannabis et d'autres drogues illicites chez une population de victimes de traumatismes dans un grand centre canadien de traumatologie de London, en Ontario, au cours des 3 mois précédant ( $1^{\text {er }}$ juillet au 30 septembre 2018) et des 3 mois suivant ( $1^{\text {er }}$ novembre 2018 au 31 janvier 2019) la légalisation du cannabis au Canada. La consommation de cannabis était confirmée par l'obtention de résultats positifs aux tests de dépistage des cannabinoïdes demandés par l'équipe de traumatologie. Nous avons aussi effectué un dépistage des opioïdes, des amphétamines et de la cocaïne.

Résultats : En tout, notre service de traumatologie a vu 210 patients entre le $1^{\text {er }}$ juillet et le 30 septembre 2018, et 141 entre le $1^{\text {er }}$ novembre 2018 et le 31 janvier 2019. Les accidents de la route ont été la plus fréquente cause de traumatisme avant (101 [48,1\%]) et après (67 [47,5\%]) la légalisation. L'indice moyen de gravité des blessures a été de 17,6 (écart-type [É.-T.] 13,0) et 19,7 (É.-T. 14,8), respectivement. Un dépistage de drogues a été effectué chez 88 patients $(41,9 \%)$ vus avant la légalisation et chez 99 patients $(70,2 \%)$ vus après la légalisation. On n'a observé aucune différence 
quant aux taux de résultats positifs aux tests de dépistage des cannabinoïdes enregistrés avant et après la légalisation $(22[25 \%]$ c. 22 [22\%]). Les taux de résultats positifs aux tests de dépistage des cannabinoïdes $(2 / 10$ [20\%] c. 5/8 [62\%]) et aux tests toxicologiques $(5 / 10[50 \%]$ c. $6 / 8[75 \%])$ ont eu tendance à être plus élevés après la légalisation chez les patients victimes de traumatismes pénétrants, mais notre échantillon était trop petit pour atteindre une portée statistique.

Conclusion : Nous n'avons observé aucune différence quant aux taux de résultats positifs au dépistage des cannabinoïdes au cours des 3 mois précédant et suivant la légalisation du cannabis; par contre, les taux de résultats positifs aux tests de dépistage des drogues et du cannabis ont eu tendance à être plus élevés chez les victimes de traumatismes pénétrants. Ces données préliminaires provenant d'un seul centre qui ne montrent pas d'augmentation des taux de consommation de cannabis chez les polytraumatisés sont rassurantes.

0 n Oct. 17, 2018, the federal Cannabis Act came into force in Canada, making this country only the second country in the world to legalize the cultivation, acquisition, possession and consumption of cannabis and its by-products. ${ }^{1}$ Previous medical literature has identified a high prevalence of positive results of screening for illicit drugs and alcohol among patients with trauma..$^{2-4}$ In the weeks leading up to the legalization of cannabis in Canada, police chiefs and physicians expressed concern regarding a potential increase in motor vehicle collisions due to impaired driving leading to an increase in trauma volumes. ${ }^{5,6}$

This unique situation provided us with an opportunity to evaluate the impact of the legislation legalizing the recreational use of cannabis on drug-related trauma. The objectives of the present study were to describe the rates of drug screens with positive results for cannabinoids and other drugs (cocaine, amphetamines and opioids) in the 3 months before and the 3 months after the legalization of recreational cannabis in Canada.

\section{Methods}

\section{Study design and setting}

We conducted a prospective observational study of all adult patients with trauma admitted to a lead Canadian trauma centre in London, Ontario, in the 3 months before (July 1 to Sept. 30, 2018) and the 3 months after (Nov. 1, 2018 , to Jan. 31, 2019) the legalization of recreational cannabis in Canada. A waived-consent model was granted. The study received approval from the Health Sciences Research Ethics Board at Western University (HSREB $113752)$.

\section{Data source}

We gathered data on all adult patients admitted to our trauma service between July 1, 2018, and Jan. 31, 2019. This began as a quality-improvement initiative to help our trauma providers better appreciate the rates of positive results of drug screens in our patients. As such, urine toxicology screens were ordered on admission (but before administration of any opioids) in all adult patients with trauma during the 6-month study period. Our urine toxicology screens assess for cannabinoids, opioids, amphetamines and cocaine.

\section{Patient selection}

All adult patients with trauma referred directly to our trauma service during the 6-month study period were eligible for study inclusion. Those referred from other hospitals were not included as they may have received opiates from their medical providers, which would cloud our assessment of their urine drug screens. Patients who received opiates in the prehospital setting were also excluded.

\section{Statistical analysis}

We used descriptive statistics (mean and standard deviation [SD] or median and interquartile range) to summarize patient characteristics. We compared rates of positive toxicology screen results using the Pearson $\chi^{2}$ test except when expected cell counts were less than 5 , in which case we used the Fisher exact test.

\section{REsults}

A total of 210 patients were referred directly to the trauma service in the 3 months before cannabis legalization, and 141 were referred in the 3 months after legalization. The mean age was 49.6 (SD 20.5) years and 51.1 (SD 20.7) years, respectively (Table 1). The gender distribution was similar in the 2 periods. Motor vehicle collisions were the most common cause of trauma both before legalization (101 [48.1\%]) and after legalization (67 [47.5\%]), followed by falls (46 [21.9\%] and 41 [29.1\%], respectively) and penetrating trauma (21 [10.0\%] and 13 [9.2\%], respectively). The mean Injury Severity Score was 17.6 (SD 13.0) before legalization and 19.7 (SD 14.8) after legalization.

Drug screens were done in 88 patients $(41.9 \%)$ before legalization and 99 patients $(70.2 \%)$ after legalization. 


\begin{tabular}{|c|c|c|c|}
\hline \multirow[b]{2}{*}{ Characteristic } & \multicolumn{3}{|c|}{ No. $(\%)$ of patients* } \\
\hline & $\begin{array}{l}\text { Before legalizationt } \\
\qquad n=210\end{array}$ & $\begin{array}{l}\text { After legalization } \neq \\
\qquad n=141\end{array}$ & $\begin{array}{l}\text { Overall } \\
n=351\end{array}$ \\
\hline Age, mean $\pm S D, y r$ & $49.6 \pm 20.5$ & $51.1 \pm 20.7$ & $50.2 \pm 20.5$ \\
\hline Male sex & $148(70.5)$ & $99(70.2)$ & $247(70.4)$ \\
\hline \multicolumn{4}{|l|}{ Mechanism of injury } \\
\hline Motor vehicle collision & $101(48.1)$ & $67(47.5)$ & $168(47.9)$ \\
\hline Fall & $46(21.9)$ & $41(29.1)$ & $87(24.8)$ \\
\hline Recreational vehicle & $10(4.8)$ & $1(0.7)$ & $11(3.1)$ \\
\hline Other blunt & $4(1.9)$ & $8(5.7)$ & $12(3.4)$ \\
\hline Penetrating & $21(10.0)$ & $13(9.2)$ & $34(9.7)$ \\
\hline Other & $28(13.3)$ & $11(7.8)$ & $39(11.1)$ \\
\hline Injury Severity Score, mean \pm SD & $17.6 \pm 13.0$ & $19.7 \pm 14.8$ & $18.4 \pm 13.7$ \\
\hline \multicolumn{4}{|c|}{ Maximum Abbreviated Injury Scale score, mean \pm SD } \\
\hline Head & $2.9 \pm 1.5$ & $3.0 \pm 1.4$ & $2.9 \pm 1.4$ \\
\hline Face & $1.4 \pm 0.6$ & $1.4 \pm 0.5$ & $1.4 \pm 0.6$ \\
\hline Neck & $1.5 \pm 0.8$ & $2.3 \pm 1.0$ & $2.0 \pm 1.0$ \\
\hline Thorax & $2.9 \pm 1.1$ & $3.0 \pm 0.9$ & $2.9 \pm 1.0$ \\
\hline Abdomen & $2.0 \pm 1.1$ & $2.3 \pm 1.0$ & $2.1 \pm 1.1$ \\
\hline Upper extremity & $2.3 \pm 0.6$ & $2.3 \pm 0.6$ & $2.3 \pm 0.6$ \\
\hline Lower extremity & $2.1 \pm 1.1$ & $2.0 \pm 1.0$ & $2.0 \pm 1.0$ \\
\hline External & $1.0 \pm 0.0$ & $1.0 \pm 0.0$ & $1.0 \pm 0.0$ \\
\hline Other§ & $4.0 \pm 1.7$ & 2.09 & $3.5 \pm 1.7$ \\
\hline $\begin{array}{l}\text { SD }=\text { standard deviation. } \\
\text { *Except where noted otherwise. } \\
\text { tJuly } 1 \text { to Sept. 30, } 2018 . \\
\text { tNov. } 1,2018, \text { to Jan. } 31,2019 \text {. } \\
\text { \$Hypothermia, multiple contusions to en } \\
\text { In } n=1 .\end{array}$ & body, asphyxiation with & lac arrest. & \\
\hline
\end{tabular}

There was no difference in the rate of positive cannabinoid screen results between the 2 periods ( $25 \%$ v. $22 \%, p=0.7)$. The rate of positive toxicology screen results was higher before legalization than after legalization $(50 \%$ v. $33 \%, p=$ 0.02) (Table 2).

In the subgroup of patients whose mechanism of trauma was a motor vehicle collision, there was no difference in the rate of positive toxicology screen results or positive cannabinoid screen results between the 2 periods (Table 2). Among patients with penetrating trauma, there was a trend toward a difference in the rate of positive cannabinoid screen results (20\% before legalization v. $62 \%$ after legalization) and positive toxicology screen results (50\% positive before legalization v. $75 \%$ after legalization), but our sample was too small to achieve statistical significance (Table 2).

\section{Discussion}

We found that the rate of positive cannabinoid screen results among patients with trauma referred directly to our trauma service was similar in the 3 months before and the 3 months after the legalization of recreational cannabis in Canada. The rates of positive cannabis screen results were already high before cannabis legalization, and

\begin{tabular}{|c|c|c|c|}
\hline \multirow[b]{2}{*}{ Type of screen } & \multicolumn{2}{|c|}{ No. $(\%)$ of patients } & \multirow[b]{2}{*}{$p$ value } \\
\hline & $\begin{array}{l}\text { Before } \\
\text { legalization }\end{array}$ & $\begin{array}{c}\text { After } \\
\text { legalization }\end{array}$ & \\
\hline All patients & $n=88$ & $n=99$ & \\
\hline Toxicology screen & $44(50)$ & 33 (33) & $0.02 \dagger$ \\
\hline Cannabis screen & $22(25)$ & $22(22)$ & $0.7 \dagger$ \\
\hline $\begin{array}{l}\text { Patients with trauma due to } \\
\text { motor vehicle collision }\end{array}$ & $n=51$ & $n=54$ & \\
\hline Toxicology screen & $24(47)$ & $17(32)$ & $0.1 \dagger$ \\
\hline Cannabis screen & $14(28)$ & $11(20)$ & $0.4 \dagger$ \\
\hline $\begin{array}{l}\text { Patients with penetrating } \\
\text { trauma }\end{array}$ & $n=10$ & $n=8$ & \\
\hline Toxicology screen & $5(50)$ & $6(75)$ & $0.4 \ddagger$ \\
\hline Cannabis screen & $2(20)$ & $5(62)$ & $0.1 \neq$ \\
\hline \multicolumn{4}{|c|}{$\begin{array}{l}\text { *Urine screen for cannabinoids, amphetamines, cocaine and opioids. } \\
+\chi^{2} \text { test. }\end{array}$} \\
\hline
\end{tabular}

legalization did not seem to increase the number of patients with trauma testing positive for cannabis. In addition, the number of patients with trauma and the proportion of trauma cases due to motor vehicle collisions decreased in the 3 months after legalization. These latter findings are likely due to the season rather than being 
related to cannabis legalization, as the date of legalization, Oct. 17, fell after our busy summer trauma season.

There was a decrease in the rate of positive toxicology screen results after cannabis legalization. This finding was unexpected and is difficult to explain. Interestingly, when we looked at the data for patients with trauma due to motor vehicle collisions alone, there was no difference in the rates of positive results of cannabinoid screens or toxicology screens. The only increases in positive toxicology screen results that we identified occurred in the subgroup of patients with penetrating trauma, who had increases in positive results of both cannabinoid testing and general urine toxicology screens.

\section{Limitations}

The conclusions that can be drawn from our findings are limited by the study's single-centre nature. Although toxicology screens were obtained for about half of the patients, which provided a robust sample size, the number of patients with penetrating trauma was low, which precluded any definitive conclusions. The toxicology screen results may have been falsely elevated owing to patients' having received opiates at referring centres without our knowledge. This, of course, would not have affected the rate of positive results of cannabinoid screens. We acknowledge that a positive urine test result indicates that a patient has been exposed to illicit drugs but does not imply that the drug exposure caused the motor vehicle collision or trauma. In addition, owing to the toxicokinetics of specific drugs, some may have been used days before the index trauma. Nevertheless, although the urine toxicology screen has its limitations, it is still a useful metric given the objectives of our study.

\section{Conclusion}

At our lead Canadian trauma centre, there was no difference in the rates of positive urine cannabinoid screens before and after the legalization of cannabis. We identified no change in the rates of positive urine cannabinoid or toxicology screens after cannabis legalization in the subgroup of patients with motor vehicle collisions as their mechanism of traumatic injury. These preliminary singlecentre data showing no increased rates of cannabis use in patients with trauma after legalization are reassuring.

Affiliations: from the Department of Surgery, Western University, London, Ont. (Vogt, Parry); the Division of Emergency Medicine, Department of Medicine, Western University, London, Ont. (Pace, Ball); and the London Health Sciences Trauma Program, London, Ont. (Priestap).

\section{Competing interests: None declared.}

Contributors: I. Ball, J. Pace and K. Vogt designed the study. I. Ball and F. Priestap acquired the data, which I. Ball, F. Priestap, N. Parry and K. Vogt analyzed. I. Ball and F. Priestap wrote the article, which I. Ball, N. Parry, J. Pace and K. Vogt critically reviewed. All authors approved the article for publication.

Content licence: This is an Open Access article distributed in accordance with the terms of the Creative Commons Attribution (CC BYNC-ND 4.0) licence, which permits use, distribution and reproduction in any medium, provided that the original publication is properly cited, the use is noncommercial (i.e., research or educational use), and no modifications or adaptations are made. See: https://creativecommons. org/licenses/by-nc-nd/4.0/.

\section{References}

1. Sapra B. Canada becomes second nation in the world to legalize marijuana. CNN Health 2018 June 20. Available https://www.cnn.com/ 2018/06/20/health/canada-legalizes-marijuana/index.html (accessed 2019 Oct. 3).

2. Madan AK, Yu K, Beech D. Alcohol and drug use in victims of lifethreatening trauma. 7 Trauma 1999;47:568-71.

3. Levy RS, Hebert CK, Munn BG, et al. Drug and alcohol use in orthopedic trauma patients: a prospective study. 7 Orthop Trauma 1996; 10:21-7.

4. Cowperthwaite MC, Burnett MG. Treatment course and outcomes following drug and alcohol related traumatic injuries. 7 Trauma Manag Outcomes 2011;5:3.

5. Draaisma M. Minister confident police in Canada ready for cannabis legalization next week. CBC News 2018 Oct. 9. Available: https:// www.cbc.ca/news/canada/toronto/bill-blair-marijuana-legalization -police-forces-ready-1.4855258 (accessed 2019 Oct. 3).

6. Grant K. What Canada's doctors are concerned about with marijuana legalization. Globe and Mail [Toronto] 2018 Oct. 9; updated 2018 Nov. 28. Available: https://www.theglobeandmail.com/cannabis/ article-what-canadas-doctors-are-concerned-about-with-marijuana -legalization-2/ (accessed 2019 Oct. 3). 